\title{
Solving the Nonstationary Problem of the Disperse Phase Concentration during the Pneumoclassification Process of Mechanical Mixtures
} \\ ${ }^{1}$ Sumy State University, 2 Rymskogo-Korsakova St., 40007 Sumy, Ukraine; \\ ${ }^{2}$ Technical University of Kosice, 1/9 Letna St., 04001 Kosice, Slovak Republic
}

\section{Article info:}

Paper received:

The final version of the paper received:

Paper accepted online:
July 10, 2018

December 18, 2018

December 23, 2018
*Corresponding Author's Address:

yukhimenko@pohnp.sumdu.edu.ua

\begin{abstract}
The article dials with studying of the gas-dispersed systems classification process in gravitation pneumoclassifiers of prismatic shape. The aim of the research is to determine operating parameters of the investigated process. Recent research is based on the previously developed mathematical model of hydrodynamics for a gasdispersed flow in a vertical channel with variable cross-section. As a development of this study, a physical model based on the process of kinetic removal from the mixture was used. This process is caused by the removal of fine particles from the weighed layer in the case of theirs low velocities in comparison with the average gas flow velocity. This model also considers the inertial effect due to the kinetic energy of fine particles removed from the surface of the weighted later. The first order linear nonhomogeneous partial differential equation describing the unsteady process of changing the dispersed phase concentration in the gas-mechanical mixture by channel height was solved by mathematical modeling using the combination of direct and inverse Laplace transforms. As a result, for the first time the general solution was obtained for for non-trivial boundary and initial conditions. This fact allowed developing the mathematical model of the nonstationary problem for the disperse phase concentration during the pneumoclassification process of mechanical mixtures in pneumoclassifiers. The model allows determining the concentration of fine fraction of the gas-dispersed mixture by channel height in operating volume of the device, as well as evaluating time of the pneumoclassification process. Particularly, it was found that the dispersed phase concentration decreases by the height of the apparatus with respect to time. This fact proves the possibility of effective separation of components in gas-mechanical mixtures. Finally, the achieved results allow proposing the engineering technique for calculations of vertial-type gravitation pneumoclassifiers.
\end{abstract}

Keywords: pneumoclassifier, weighted layer, fine particles, agglomeration, mathematical modeling, Laplace transform, Heaviside step function.

\section{Introduction}

The increase of the efficiency of chemical, heat and mass transfer processes for heterogeneous systems is mainly achieved using powdering of solid materials with a given granulometric composition. Therefore, in technological lines, pneumoclassifiers are installed to separate the solid phase of gas-liquid mixtures into two fractions with a predominant content of fine particles. If the dust content is less than 15-20\%, pneumoclassifiers are effectively used as separators for the decomposition of mixtures. When separating of binary mixtures with the equal content of fine and coarse fractions, traditionall pneumoclassifiers ensure the purity of the resulting fractions up to $70-75 \%$. Due to the existence of technologies requiring clean separation products not less than $95 \%$, it is the development of new designs of separation equipment is needed realizing fundamentally different organization of the pneumoclassification process and pneumatic enrichment of gas-mechanical mixtures to obtain clean separation products. In this case, mathematical modeling of the separation process in a gravitational pneumoclassifier is an urgent problem, which is essential for the study of chemical technology processes. The scientific novelty of the research confirms the need to solve the insufficiently solved problem of investigating the pneumatic classification and enrichment processes for mechanical mixtures. The practical significance of the achieved results is to improve up-to-date scientifically based methods for calculations of main technological parameters and related characteristics of pneumoclassifiers. 


\section{Literature Review}

The first ways for improvement of pneumoclassifiers were proposed in the research works $[1,2]$. As a result, modifications of classifier designs with mobile inclined grid were proposed for increasing of the operating process efficiency.

The investigation of the classification process for polydisperse materials in the gravitational air classifier was considered within the previous research [3]. As a result, the problem of the separation efficiency was solved for polydisperse materials, as well as methods for increasing the separation quality are proposed. Additionally, the results of experimental research and computer simulation were obtained and analyzed. Based on the achieved data, the possibility of increasing gas flow influence to polydispersed materials were found.

The effect of particle concentration on fluctuating velocity of the disperse phase for turbulent pipe flow was investigated in the paper [4]. As a result, experimental investigations of the fluctuation velocity distributions of solid particles were presented for the gas turbulent pipe flow. An influence of the particle concentration on the increasing of axial fluctuation velocity in the pipe wall region was observed.

In the paper [5], a concentrated suspension flow of solid spherical particles was modelled using numerical experiment. As a result, the self-diffusion coefficient was obtained. It was shown that spheres at volume fraction about $13 \%$ form a percolation cluster. Finally, the dependence of the self-diffusion coefficient on volume fraction of particles was investigated.

The research papers [6-9] dials with the process of agglomeration as a common phenomenon in separation and pneumiclassification processes. As a result of using the Rumpf model [6] and related numerical simulations, it is proved that the mechanical properties of agglomerates depend on their structures. It was proved that the acoustic agglomeration technology can be applied for removal of fine particles [7]. Comparison of agglomeration behavior of fine particles in during mixing is presented in the paper [8]. Finally, ways for experimental evaluation of chemical agglomeration of fine particles in gas-mechanical mixtures are presented in the research work [9].

\section{Research Methodology}

Previously obtained equations [3] allows determining the velocity field of the two-phase flow, as well as evaluating changes of particles velocities of mixed material by the width and height of pneumoclassifier's housing depending on the gas flow action.

It should be noted that the action of friction forces on the particles, flow compression and bending forces between particles significantly impact on the redistribution of particle velocity in the separated flow. At the same time, the gas flow rate decreases due to the additional hydraulic resistance as a result of aggregation of the bulk material in agglomerates.
Due to abovementioned, the process of fine fracture concentration changing in a pneumoclassifier of the prismatic form with veriable cross-sections is considered with respect to time and spatial position of particles (Figure 1).

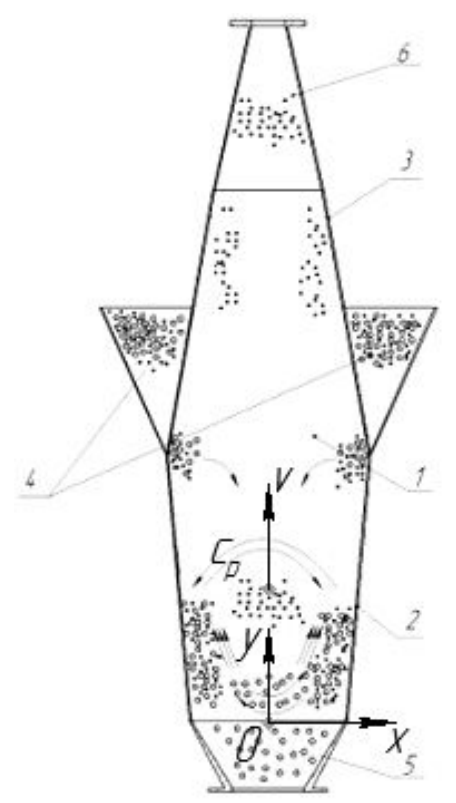

Figure 1 - Design scheme of the pneumoclassifier: 1 - separation zone; 2 - housing; 3 - accelerating zone; 4 - loading hopper; 5 - discharge pipe for a coarse fraction; 6 - discharge pipe for a fine fraction

In the case of unchangeable physical parameters in a transverse direction $(\partial / \partial x=0)$ and relatively insufficient transverse velocity component $(|d x / d t| \ll|v(y)|)$, the equation describing the operating process takes the following form [10]:

$$
\frac{\partial c_{p}(y, t)}{\partial t}=v(y) \frac{\partial c_{p}(y, t)}{\partial y}+k_{y}\left[c_{*}-c_{p}(y, t)\right],
$$

where $t$ - time, s; $x, y$-transverse and vertical coordinates, $\mathrm{m} ; v$ - vertical component of flow velocity, $\mathrm{m} / \mathrm{s}$; $c_{p}$ - concentration of fine particle in a flow, $\mathrm{kg} / \mathrm{kg}$; $c_{*}$ - equilibrium concentration of fine fraction in a weighted mode, $\mathrm{kg} / \mathrm{kg} ; k_{y}$ - removal ratio determining experimentally, $\mathrm{s}^{-1}$.

Abovementioned simplifications are argued due to the fact, that the width of the pneumoclassifier is much less than its height. Additionally, the velocity of solid particles in the horizontal direction (from the $x$ axis of the apparatus to the walls) significantly decreases due to the inhibitory effect. Therefore, the gas flow in the transverse direction does not significantly impact on the separation of particles by their size.

The equation (1) defines the removal of fine particles from the weighed layer in the case of theirs low velocities in comparison with the average gas flow velocity. In the case of the relatively constant velocity $v$, this equation has the precise analytical solution, which can be obtained 
using the Laplace transform [11] with respect to time $t$. The corresponding originals and their mappings can be given in the following forms:

$$
\begin{aligned}
& L\left[c_{p}(y, t)\right]=C_{p}(y, s) ; L\left(c_{*}\right)=\frac{c_{*}}{s}, \\
& L\left[\frac{\partial c_{p}(y, t)}{\partial t}\right]=s C_{p}(y, s)-c_{p 0}(y),
\end{aligned}
$$

where $Y, s$-new parameters of the vertical coordinate $y$ and time $t$ respectively; $C_{p}$ - reflecting function for the fine fraction concentration; $c_{p 0}(y)$ - distribution function of the initial concentration.

After applying transformations (2), the equation (1) takes the following form:

$$
s C_{p}(y, s)-c_{p 0}(y)=v \frac{\partial C_{p}(y, s)}{\partial y}+k_{y}\left[\frac{c_{*}}{s}-C_{p}(y, s)\right] .
$$

Identical transformations allow obtaining the following first-order heterogeneous ordinary differential equation with respect to the vertical coordinate $y$ :

$$
C_{p}^{\prime}+\frac{s-k}{v(y)} C_{p}=\frac{1}{v(y)}\left[c_{p 0}(y)-\frac{k_{y} c_{*}}{s}\right]
$$

Previous research of the two-phase flow indicates the fact, that the trajectories of fine particles are aligned by the channel height. Consequently, the gas flow does not significantly affect the shearing of particles to the wall. In this case, considering $v=$ const, $c_{p 0}=$ const, the differential equation (4) has the following general solution:

$$
C_{p}=\frac{1}{s-k}\left(c_{p 0}-\frac{k c_{*}}{s}\right)+A \cdot \exp \left(-\frac{s-k}{v} z\right)
$$

where $A$ - the integration constant determined from the boundary condition:

$$
c_{p}(0, t)=c_{p}^{i n},
$$

which can be rewritten after the direct Laplace transform in the following form:

$$
C_{p}(0, s)=L\left[c_{p}(0, t)\right]=\frac{c_{p}^{i n}}{s} .
$$

The last two formulas contain the initial concentration $c_{p}{ }^{\text {in }}$ of the disperse phase.

The substitution of the boundary condition (7) into the formula (5) allows obtaining the following expression for the integration constant:

$$
A=\frac{c_{p}^{i n}}{s}-\frac{1}{s-k}\left(c_{p 0}-\frac{k c_{*}}{s}\right)
$$

Hence, the general solution (5) takes the following form:

$$
C_{p}=\frac{c_{p}^{i n}}{s} e^{-\frac{s-k}{v} z}+\left(\frac{c_{*}}{s}+\frac{c_{p 0}-c_{*}}{s-k}\right)\left(1-e^{-\frac{s-k}{v} z}\right) .
$$

Using the inverse Laplace transform to elements of the obtained expression:

$$
\begin{aligned}
& L^{-1}\left(\frac{c_{p}^{i n}}{s} e^{-\frac{s-k}{v}}\right)=c_{p}^{i n} e^{-\frac{k}{v} y} H\left(t-\frac{y}{v}\right) ; \\
& L^{-1}\left(\frac{c_{*}}{s}\right)=c_{*} ; L^{-1}\left(\frac{c_{p 0}-c_{*}}{s-k}\right)=\left(c_{p 0}-c_{*}\right) e^{-k t} ; \\
& L^{-1}\left(\frac{c_{p 0}-c_{*}}{s-k} e^{-\frac{s-k}{v}}\right)=\left(c_{p 0}-c_{*}\right) e^{-k t} H\left(t-\frac{y}{v}\right),
\end{aligned}
$$

where $H(t)$ - Heaviside step function, allows finally obtaining the expression for the distribution function of the disperse phase concentration:

$$
\begin{aligned}
& c_{p}(y, t)=c_{*}+\left(c_{p}^{i n}-c_{*}\right) e^{-\frac{k}{v} y} H\left(t-\frac{y}{v}\right)+ \\
& +\left(c_{0}-c_{*}\right) e^{-k t}\left[1-H\left(t-\frac{y}{v}\right)\right] .
\end{aligned}
$$

\section{Results and Discussion}

A general solution of the nonstationary problem of the disperse phase concentration during the pneumoclassification process of mechanical mixtures can be obtained ubder the condition $c_{p}{ }^{\text {in }}=c_{p 0}$ :

$$
\begin{aligned}
& c_{p}(y, t)=c_{*}+\left(c_{p 0}-c_{*}\right)\left\{\exp \left(-\frac{k}{v} y\right) H\left(t-\frac{y}{v}\right)+\right. \\
& \left.+\exp (-k t)\left[1-H\left(t-\frac{y}{v}\right)\right]\right\} .
\end{aligned}
$$

It should be noted that this solution approaches the following curve asymptotically with respect to time:

$$
c_{p \infty}(y)=\lim _{t \rightarrow \infty} c_{p}(y, t)=c_{*}+\left(c_{p 0}-c_{*}\right) \exp \left(-\frac{k}{v} y\right) .
$$

This equation describes the equilibrium state as a result of the solution of stationary problem of fine particles concentration.

Introducing the dimensionless coordinates

$$
\eta=\frac{k y}{v} ; \tau=\frac{v t}{y}
$$

and criteria

$$
\bar{c}_{p}=\frac{c_{p}}{c_{p 0}} ; \alpha=\frac{c_{*}}{c_{p 0}} ; \bar{c}_{p \infty}=\frac{c_{p \infty}}{c_{p 0}}
$$


allows rewriting the dependencies (12) and (13) in the following universal forms:

$$
\begin{gathered}
\bar{c}_{p}(\eta, \tau)=\alpha+(1-\alpha)\left\{e^{-\eta} H(\tau-1)+\right. \\
\left.+e^{-\eta \tau}[1-H(\tau-1)]\right\} ; \\
\bar{c}_{p \infty}(\eta)=\alpha+(1-\alpha) e^{-\eta}
\end{gathered}
$$

presented graphically in Figures 2, 3 .

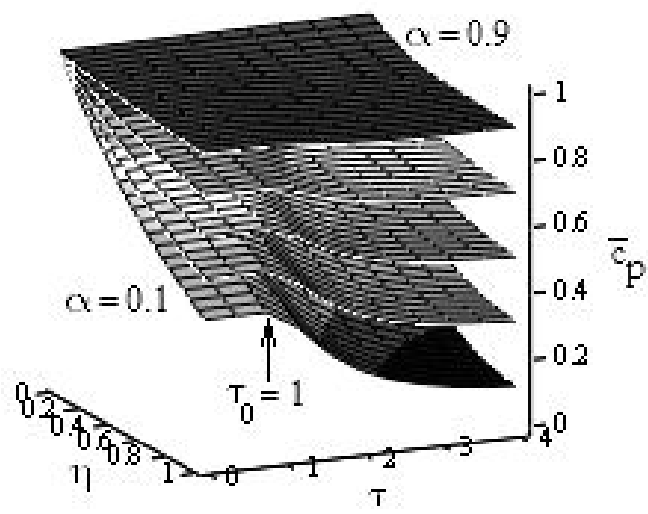

Figure 2 - The surface of changing the fine particles concentration in a weighed layer by the height of the apparatus and time for different values of equilibrium concentration

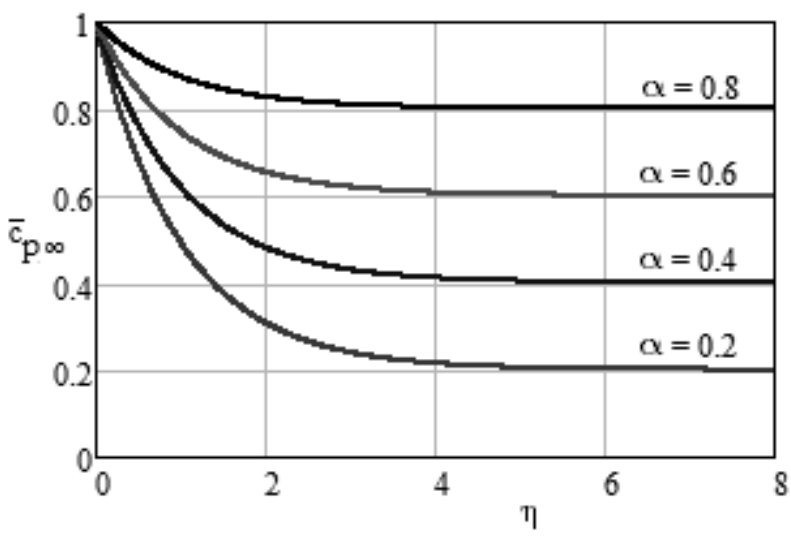

Figure 3 - Universal characteristics of changing the fine particles concentration in a weighed layer by the height of the apparatus for the equilibrium state
Figure 2 discovers the existence of the dimensionless time $\tau_{0}=1$ as a limit value, when the concentration decreases by the height. Consequently, due to the dependencies (14), the related time is determined by the following formula:

$$
t_{0}=\left.\frac{y \tau}{v}\right|_{\tau=\tau_{0}=1}=\frac{y}{v} .
$$

\section{Conclusions}

Mathematical model of the pneumoclassification process is developed. As a result, the nonstationary problem of investigating the operating processes in gravitational pneumoclassifiers is solved. The analytical dependence for the fine particles concentration is obtained. As a partial result of the solution of stationary problem, the expression for equilibrium concentration is determined. Additionally, the critical time is discovered, when the concentration decreases by the height, as well as the related expression for its calculation is obtained. Overall, the possibility of effective separation of components in gas-mechanical mixtures is proved.

The results of the abovementioned research allow proposing the engineering technique for calculations of vertial-type gravitation pneumoclassifiers.

The further research will be aimed at the implementation of the developed mathematical model in the process of designing the module separation equipment.

\section{Acknowledgements}

The main theoretical results was obtained within the research project of the Faculty of Technical Systems and Energy Efficient Technologies of Sumy State University "Development and implementation of energy efficient modular separation devices for oil and gas purification equipment" (State reg. No. 0117U003931) ordered by the Ministry of Education and Science Ukraine.

The numerical calculations were realized within the research collaboration between Sumy State University and Technical University of Kosice.

\section{References}

1. Makarenko, E. S. (1992). Improvement pneumoclassifier with inclined mobile grid. Koks i Khimiya, Vol. 1, pp. 31-32.

2. Kasimov, A. M., Makarenko, E. S., Shuvalov, E. A. (1992). Modification of pneumoclassifier with inclined air distributive grid for strong materials. Ogneupory, Vol. 3, pp. 33.

3. Varukha, D. A., Smirnov, V. A., Edl, M., Demianenko, M. M., Yukhymenko, M. P., Pavlenko, I. V., \& Liaposhchenko, O. O. (2018). Simulation of separation and air classification processes of aerodisperse systems in the shelving device. Journal of Engineering Sciences, Volume 5(1), pp. F5-F9.

4. Varaksin, A. Yu., Polezhaev, Yu. V., \& Polyakov, A. F. (2000). Effect of particle concentration on fluctuating velocity of the disperse phase for turbulent pipe flow. International Journal of Heat and Fluid Flow, Vol. 21(5), pp. 562-567.

5. Lukyanov, A., Andreev, V., \& Pozdyshev, V. (1990). Influence of disperse phase concentration on character of Brownian motion of particles. Journal of Colloid And Interface Science, Vol. 137(1), pp. 111-119. 
6. Yang, R. Y., Yu, A.B., Choi, S. K., Coates, M. S., \& Chan, H.K. (2007). Agglomeration of fine particles subjected to centripetal compaction. Powder Technology, Vol. 184(1), pp. 122-129.

7. Shi, C.-H., Zhang, J., Zhao, Y., \& Liang, J. (2017). Acoustic Agglomeration Process of Fine Particles in a Resonance Structure. IOP Conference Series: Earth and Environmental Science, Vol. 78, 012001, doi: 10.1088/1755-1315/78/1/012001.

8. Sumimoto, S., Yoshimoto, K., Uddin, A., \& Kato, Y. (2017). Comparison of Agglomeration Behavior of Fine Particles in Liquid among Various Mixing Operations. ISIJ International, Vol. 58(1), pp. 1-9.

9. Guo, Y., Zhang, J., Zhao, Y., Wang, S., Jiang, C., \& Zheng, C. (2017). Chemical agglomeration of fine particles in coal combu stion flue gas: Experimental evaluation. Fuel, Vol. 203, pp. 557-569.

10. Kafarov, V. V., Dorokhov, I. N. (2018). Systematic analysis of the chemical technologies processes: Fundamental strategies. Urait, Moscow [in Russian].

11. Rodrigo, M. R., \& Worthy, A. L. (2016). Solution of multilayer diffusion problems via the Laplace transform. Journal of Mathematical Analysis and Applications, Vol, 444(1), pp. 475-502.

\title{
Розв'язання нестаціонарної задачі про визначення концентрації дисперсної фази у процесі пневмокласифікації механічних сумішей
}

\author{
Павленко І. В. ${ }^{1}$ Юхименко М. П. ${ }^{1}$, Литвиненко А. В. ${ }^{1}$, Боцко Й. ${ }^{2}$ \\ ${ }^{1}$ Сумський державний університет, вул. Римського-Корсакова, 2, 40007, м. Суми, Україна; \\ ${ }^{2}$ Технічний університет м. Кошице, вул. Літня, 1/9, 040 01, м. Кошице, Словаччина
}

\begin{abstract}
Анотація. Робота присвячена дослідженню процесу класифікації газодисперсних систем у гравітаційних пневмокласифікаторах призматичної форми. Метою роботи $\epsilon$ встановлення робочих параметрів досліджуваного процессу, в основі якого $\epsilon$ попередньо розроблена математична модель гідродинаміки руху газодисперсного потоку у вертикальному каналі змінного перерізу. Як розвиток цього дослідження, застосовано фізичну модель, засновану на процесі кінетичного винесення суміші, обумовленого винесення дрібних частинок взваженого шару, швидкість яких менша за швидкість газового потоку. Ця модель також ураховує інерційний ефект, обумовлений кінетичною енергією дисперсної фази, що виноситься 3 поверхні зваженого шару. Шляхом математичного моделювання із застосуванням комбінації прямого і оберненого перетворень Лапласа розв'язано лінійне неоднорідне диференціальне рівняння першого порядку у частинних похідних, що описує нестаціонарний процес зміни концентрації дисперсної фази газомеханічної суміші по висоті каналу. У результаті для нетривіальних граничних і початкових умов вперше отримано загальний розв'язок, що дозволило розробити математичну модель нестаціонарної задачі про визначення концентрації дисперсної фази у пневмокласифікаторах. Розроблена математична модель дозволяє встановити зміну концентрації дрібної фракції газодисперсної суміші по висоті робочого об'єму апарата, а також оцінити час процесу пневмокласифікації. Зокрема, встановлено, що концентрація дисперсної фази з часом зменшується по висоті апарату, що свідчить про можливість ефективного розділення компонентів газомеханічної суміші. Таким чином, отримані результати дозволяють створити інженерну методику розрахунку вертикальних гравітаційних пневмокласифікаторів призматичної форми зі змінним поперечним перерізом.
\end{abstract}

Ключові слова: пневмокласифікатор, взважений шар, дрібна фракція, агломерація, математичне моделювання, перетворення Лапласа, функція Хевісайда. 